\title{
THE FUTILE FORGIVENESS: BASING DEPORTATION ON AN EXPUNGED NARCOTICS CONVICTION
}

Deportation may work severe hardship, causing a complete break of established social and economic ties. This fact has led to a doctrine of judicial leniency towards aliens ordered to be deported; the deportation statutes are to be strictly construed and all doubts as to their construction are to be resolved in favor of the alien. ${ }^{1}$ While recognizing the continuing existence of this doctrine, the Ninth Circuit Court of Appeals in GarciaGonzales v. Immigration \& Naturalization Serv. ${ }^{2}$ and Kelly v. Immigration \& Naturalization Serv. ${ }^{3}$ recently upheld deportation orders based upon state narcotics possession convictions, despite the fact that the aliens involved had received the benefit of the California "expungement" statute. ${ }^{4}$ That statute purports to release an offender who has successfully completed a probationary period from the "penalties and disabilities of his conviction." The alien in Kelly $v$. Immigration \& Naturalization Serv., who had lived in the United States for twelve years, was a first offender; he was convicted of illegal possession of marihuana. The Garcia-Gonzales alien was a fifty-one year old woman, a resident of the United States for over forty years, who was described by the court as a "self-respecting, self-supporting member of the communities in which she has lived." 5 The decisions are harsh under the circumstances. This Comment will discuss the question whether the court was correct in its refusal to reverse the deportation orders in light of the California expungement and consider whether the present deportation statutes reflect sound policy judgment.

The federal statute upon which the deportations were based is section 241(a) (11) of the Immigration and Nationality Act of $1952,{ }^{\circ}$ which provides that "any alien in the United States . . . shall, upon the order of the Attorney General, be deported who . . . at any time has been convicted of a violation of . . a any law or regulation [dealing with illegal narcotics activities] . . . Against their orders of deportation the aliens Kelly and Garcia-Gonzales set up as a defense the expungement of

1 Barber v. Gonzales, 347 U.S. 637, 642-43 (1954); Fong Haw Tan v. Phelan, 333 U.S. 6, 10 (1948).

2344 F.2d 804 (9th Cir.), cert. denied, 34 U.S.L. WEEK 3119 (U.S. Oct. 11, 1965) (No. 389). Concerning the doctrine of judicial leniency, the court said "we are aware . . . that matters of doubt should be resolved in favor of the alien in deportation proceedings, because of the severity of the remedy invoked. (Fong Haw Tan v. Phelan, ....). Our duty, taking into account applicable rules of construction, is to ascertain the intention of Congress." 344 F.2d at 810 .

3349 F.2d 473 (9th Cir. 1965).

4 Cal. Penal Code $\$ 1203.4$.

6344 F.2d at 805.

666 Stat. 206 (1952), as amended, 8 U.S.C. $\$ 1251$ (a)(11) (1964). 
their convictions under section 1203.4 of the California Penal Code, which provides:

Every defendant who has fulfilled the conditions of his probation for the entire period thereof, or who shall have been discharged from probation prior to the termination of the period thereof, shall at any time thereafter be permitted by the court to withdraw his plea of guilty and enter a plea of not guilty; or if he has been convicted after a plea of not guilty, the court shall set aside the verdict of guilty ; and in either case the court shall thereupon dismiss the accusations or information against such defendant, who shall thereafter be released from all penalties and disabilities resulting from the offense or crime of which he has been convicted. . . . provided, that in any subsequent prosecution of such defendant for any other offense, such prior conviction may be pleaded and proved and shall have the same effect as if probation had not been granted or the accusation or information dismissed.

Dismissal of an accusation or information pursuant to this section does not permit a person to own, possess or have in his custody or control any firearm capable of being concealed upon the person or prevent his conviction under Section $12021 . .^{7}$

It is arguable that the expungement raises no question as to the propriety of the aliens' deportation. The federal statute requires only a conviction, and the expungement statute itself is intended to aid a defendant who "has been convicted." On the other hand, the purpose of the state statute is to eliminate the legacy of a criminal conviction when the defendant has served a probationary period. Recognition of the conviction for purposes of deportation would seem to defeat the express object of the statutory language. Since the deportation depends upon the state conviction, moreover, it is consistent to award equal recognition to a state procedure which claims to eliminate, in a practical sense, the impact of that conviction. That the state statute does not refer to deportation, which in any event is a matter of plenary federal power, ${ }^{8}$ does not foreclose a federal court from giving effect to the expungement.

The first federal case to consider the relevance of an expungement to immigration law was In re Ringnalda. ${ }^{9}$ It involved a petition for naturalization which had been objected to on the grounds that the alien

7 Cal. Pexal Code $\$ 1203.4$. (Emphasis added.) Section 12021, referred to in the expungement statute, says that aliens, drug addicts or convicted felons who own or possess a firearm capable of being concealed on the person are guilty of a public offense. CaI. Penal Code $\S 12021$.

8 See United States ex rel. Zapp v. District Director of Immigration, 120 F.2d 762, 764 (2d Cir. 1941) ; United States ex rel. Trinler v. Carusi, 72 F. Supp. 193, 195 (E.D. Pa. 1947), rev'd on other grounds, 166 F.2d 457 (3d Cir.), vacated and remanded for disnissal, 168 F.2d 1014 (3d Cir. 1948).

048 F. Supp. 975 (S.D. Cal. 1943). 
was not of good moral character as evidenced by his prior California conviction of negligent homicide.10 The alien had obtained an expungement under section 1203.4. The court, overruling the objection, reasoned that it "should not deprive an alien, otherwise worthy, of this privilege [of naturalization] by attaching to one of his acts a disability which the sovereign against whom he committed it has fully and entirely forgiven and wiped out." 11 Following Ringnalda the Board of Immigration Appeals seemed to accord expungements similar effect under the deportation statutes, ${ }^{12}$ which provided that a narcotics conviction, or two convictions of crimes involving moral turpitude, were grounds for deportation. ${ }^{13}$

But the Ringnalda court exaggerated the effect given the statute under California law. Moreover, Ringnalda's view became increasingly inconsistent with actual practice as California decisions whittled down the effect of section 1203.4. Ringnalda had depended heavily upon People v. Mackey, ${ }^{14}$ where the California court stated that the expungement was intended to "wipe out absolutely the entire proceeding in question in a given case and to place the defendant in the position which he would have occupied in all respects as a citizen if no accusation or information had ever been presented against him." 15 Yet there already existed a few limitations upon the effect of the statute. An expunged conviction could be pleaded in a later prosecution for another crime, ${ }^{16}$ and could be used to impeach the defendant in a subsequent prosecution. ${ }^{17}$ Moreover the case of In re Phillips ${ }^{18}$ had held that such a conviction could be used as the basis for disbarment of an attorney. Ringnalda distinguished the Phillips decision on the ground that

10 Under $\$ 307$ (a) of the Nationality Act of 1940, 54 Stat. 1142, an alien applying for naturalization had to show good moral character for the preceding five years of residence.

$1148 \mathrm{~F}$. Supp. at 978 . This statement is misleading if analyzed grammatically, for it then says that the state has wiped out and forgiven a disability-the inability to become naturalized-which is beyond the power of the state to wipe out and forgive. What it most likely means is that the state has forgiven and wiped out the act insofar as state grounded legal consequences are concerned. For a conflicting conclusion, see Holland, "Conviction" Defined, 40 J.S.B. CALIF. 36 (1965). Holland argues that in matters of immigration law the federal courts under the doctrine of Erie R.R. v. Tompkins, 304 U.S. 64 (1938), must look to state law in determining whether there has been a conviction. Erie, however, was concerned with whether state law had to be applied by a federal court and there is neither state deportation law nor state power to make such law. Assuming that the fact of conviction has been established, the question is whether this is the statutory "conviction" which is sufficient to bring the deportation law into play. The statute being a federal one, the question is one of federal law.

12 Matter of F—, 1 I. \& N. Dec. 343, 348 (1942) (dictum).

13 Immigration Act of 1917, $\$ 19,39$ Stat. 889 (now Immigration and Nationality Act $\$ 241$ (a) (11), 66 Stat. 204 (1952), as amended, 8 U.S.C. $\$ \$ 1251$ (a) (4), (11) (1964)).

1458 Cal. App. 123, 208 Pac. 135 (Dist. Ct. App. 1922).

15 Id. at 130, 208 Pac. at 138, quoted in $48 \mathrm{~F}$. Supp. at 976.

16 People v. Barwick, 7 Cal. $2 d$ 696, 699, 62 P.2d 590, 591 (1936).

17 People v. James, 40 Cal. App. 2d 740, 746-47, 105 P.2d 947, 951 (Dist. Ct. App. 1940); CAL. PeNAL CoDE $\$ 1203.4$, quoted in text at note 7 supra.

1817 Cal. 2d 55, 109 P.2d 344 (1941). 
the power to discipline officers of the court was constitutionally lodged in the judiciary and could not be dealt with by the legislature. ${ }^{19}$ This distinction vanished, however, when the Phillips case was extended to the revocation of a physician's license in Meyer v. Board of Medical Examiners. $^{20}$ Noting an additional exception to the operation of the expungement statute in the case of a driver's license revocation, ${ }^{21}$ the Meyer court concluded that the Mackey statement equating an expungee with a person against whom no information had ever been presented was incorrect. ${ }^{22}$ This limiting trend continued, often with the subsequent imprimatur of the legislature, until an expungement no longer had any effect in the case of a revocation of any of the various professional licenses. ${ }^{23}$

Faced with these developments, the California courts sought a consistent explanation of the statute's effect. In Kelly v. Municipal Court 24 the court developed the theory that perhaps "section 1203.4 has reference to criminal or quasi-criminal penalties, penalties imposed for punishment or prevention of crime, such as imprisonment, fine, posting of a bond to keep the peace, or registration and continuous and lifelong reregistration [with the police] . . . 25 The court held the requirement that sex offenders register upon a change of address to be one of the "criminal or quasi-criminal" penalties which the statute was designed to eliminate. People v. Taylor ${ }^{26}$ applied the rule of Kelly v. Municipal Court to a statute prohibiting one who had been convicted of a crime involving the use of a deadly weapon from carrying a weapon capable of being concealed upon the person. Taylor, however, was overruled by an amendment to section 1203.4 itself. ${ }^{27}$ The amendment quite effectively limited the useful-

$19 \mathrm{Id}$. at 59-60, $109 \mathrm{P} .2 \mathrm{~d}$ at 347 , discussed in $48 \mathrm{~F}$. Supp. at $977 \mathrm{n.} 1$.

2034 Cal. 2d 62, 206 P.2d 1085, 2 Stan. L. Rev. 221 (1949).

21 CAs. Vehicle Code $\$ 309$ (now CaL. Ventcle Code $\$ 13555$ ), discussed in Ellis v. Department of Motor Vehicles, 51 Cal. App. 2d 753, 757-58, 125 P.2d 521, 524 (Dist. Ct. App. 1942). (1949).

22 Meyer v. Board of Medical Examiners̀, 34 Cal. 2d 62, 67, 206 P.2d 1085, 1088

23 The inroads into $\$ 1203.4$ are listed in Garcia-Gonzales v. Immigration \& Naturalization Serv., 344 F.2d 804, 807-08 n.3 (9th Cir. 1965). This listing reads in part:

The conviction also remains effective, despite the so-called expunging: for impeachment of the offender as a witness, .. . for disbarment as an attorney, :.. for suspending a physician's license, ... for proof in an action on injuries arising out of the offense $\therefore$. There are also many statutory exceptions in the stated effect of section 1203.4: CAL. Bus. \& PROF. CODE $\$ \$ 1679$ (discipline of physicians); 2963 (discipline of licensed psychologists); 6102 (discipline of attorneys); 10,177 (discipline of licensed real estate dealers); 10,032 (discipline of licensed business opportunity brokers) ; 10,562 (discipline of mineral, oil and gas licensees); CAL. VEHICLE CODE $\$ 13,555$ (revocation of motor vehicle drivers' licenses); CAL. EDUC. CoDE $\$ \$ 12,910$, 12,811 (discipline of teachers).

24160 Cal. App. 2d 38, 324 P.2d 990 (Dist. Ct. App. 1958).

$25 I d$. at 42,324 P.2d at 992.

26178 Cal. App. 2d 472, 3 Cal. Rptr. 186 (Dist. Ct. App. 1960).

27 Cal. Stats. 1961, ch. 1735, $§ 1$, at 3744; see text at note 7 supra. 
ness of the reasoning in Kelly v. Municipal Court as to the "criminal" nature of the particular penalty.

In view of this transition in California law, there remains no support for Ringnalda's assertion that under California law an expungement means that a conviction has been "fully and entirely forgiven and wiped out." Considered from this viewpoint only, then, the decisions in Garcia-Gonzales and Kelly v. Immigration \& Naturalization Serv. were correct. The policy of deference to state law enunciated in Ringnalda, consistently applied, demands that the federal courts revise their assessment of an expungement in accordance with that made by California herself.

Ringnalda, however, contained an additional ground upon which an expungement could be given effect in deportation cases. This theory is based upon the similarity between an expungement and a pardon. Discussing a person who had received an expungement, the Ringnalda court said:

His position is not unlike that of a person pardoned. A pardon is "a purging of the offense. . . ." It "takes away poenam et culpam". . . "A pardon reaches both the punishment prescribed for the offence and the guilt of the offender; and when the pardon is full, it releases the punishment and blots out of existence the guilt, so that in the eye of the law the offender is as innocent as if he had never committed the offense. . . .28

This Ringnalda dictum was adopted by the Board of Immigration Appeals for cases arising under the deportation statutes, ${ }^{29}$ which then provided that a deportation based upon a conviction of a crime does not take place if the alien has received a pardon. ${ }^{30}$ For purposes of deportation, then, the pardon-expungement analogy is not only a matter of policy but also a matter of statutory interpretation. If there is no significant difference between an expungement and a pardon, there is no reason to treat them differently under the federal statute. With the limitations that have been made upon its effect, the expungement statute is indeed essentially similar to the California pardon statute, which reads in part:

Whenever a person is granted a full and unconditional pardon by the Governor, based upon a certificate of rehabilitation, the

28 In re Ringnalda, 48 F. Supp. 975, 976-77 (S.D. Cal. 1943).

29 Matter of E-V- V- 5 I. \& N. Dec. 194, 195-96 (1953) :

The provision in section 19(a) of the Immigration Act of 1917 regarding pardons and recommendations against deportation has been substantially incorporated in section 241 (b) of the Immigration and Nationality Act. The effect of an expungement of a record of conviction under section 1203.4 of the Penal Code of California has been held to be equivalent to a pardon.

[T] he alien . . has received the benefits of a pardon as evidenced by the expungement of the record of conviction pursuant to section 1203.4. . .

See Matter of B—, 7 I. \& N. Dec. 166, 168 (1956).

30 Immigration Act of 1917, $\$ 19,39$ Stat. 889; (repealed by Immigration and Nationality Act of 1952, $\S 241(\mathrm{~b}), 66$ Stat. 208 (1952)). 
pardon shall entitle the person to exercise thereafter all civil and political rights of citizenship, including but not limited to: (1) the right to vote; (2) the right to own, possess, and keep any type of firearm that may lawfully be owned and possessed by other citizens; except that this right shall not be restored, and Section 12001 and 12021 of the Penal Code shall apply, if the person was ever convicted of a felony involving the use of a dangerous weapon..$^{31}$

The similarity of the two procedures is perhaps best shown in the following comparison by the Taylor court of the pardon provision and the probation procedure by which defendants become eligible for expungement.

Probation ... is available only to those defendants found eligible by the proper authorities and by the court having jurisdiction. . . . [The pardon provisions] . . . deal only with pardons granted after a person has been convicted of a felony and "released from the State prison or other State institution . . . ." It is to be assumed that such person was not eligible for probation when first convicted: The pardon sections therefore provide an alternative method by which convicted felons who have served a prison term may be restored to some of the "civil and political" rights of citizens. ${ }^{32}$

There remains no practical distinction to be made between the two procedures. The requirement of registration by a sex offender is eliminated by both, ${ }^{33}$ and neither has any effect so far as the prohibition against the carrying of a concealable weapon by one convicted of a crime involving a deadly weapon. ${ }^{34}$ Nor is there any important distinction to be made as concerns the posture of an alien facing a deportation order. Since the pardon requires a certificate of rehabilitation, a pardoned alien is in the same position as the alien who has proved himself deserving of an expungement upon the termination of his probation period.

The similarity between an expungement and a pardon thus provides a persuasive argument for treating the two procedures alike for the purposes of the deportation statute. Unfortunately, this conclusion supports the correctness of the Garcia-Gonzales and Kelly v. Immigration \& Naturalization Serv. cases, because Congress in 1956 amended the pardon clause of the deportation statute to provide that it should not operate in the case

31 Cal. Penal Code $\$ 4852.17$. Section 12021, mentioned in the statute, is discussed at note 7 supra; $\$ 12001$ merely defines "weapons."

32 People v. Taylor, 178 Cal. App. 2d 472, 479-80, 3 Cal. Rptr. 186, 191 (1960).

33 Kelly v. Municipal Court, 160 Cal. App. 2d 38, 324 P.2d 990 (1958), discussed in text accompanying notes 24-27 supra, eliminated the requirement for purposes of the expungement; it is eliminated for purposes of a pardon by statute. CAL. PENAL CODE $\$ 290.5$.

34 See text at notes 7, 31 supra. 
of narcotics convictions..$^{35}$ A consistent application of the pardon-expungement analogy, then, would indicate that an expungement should be given no effect in the case of a narcotics violation.

The 1956 amendment was mentioned by the Garcia-Gonzales court, ${ }^{36}$ by reference to the Attorney General's decision in Matter of $A_{-}$ $F$

The history of $\S 241$ (a) (11) convinces me that Congress did not intend that aliens convicted of narcotic violations should escape deportation because, as in California, the State affords a procedure authorizing a technical erasure of the conviction. Traffic in narcotics has been a continuing and serious Federal concern. Congress has progressively strengthened the deportation laws dealing with aliens involved in such traffic. . . . [T] he deportation statute was amended to eliminate the requirement that . . . there must be a sentence. At the same time the statute was extended to convictions for violation of State as well as Federal statutes. And, since the 1956 amendment, an alien may no longer escape deportability by proffering a pardon. In the face of this clear national policy, I do not believe that the term "convicted" may be regarded as flexible enough to permit an alien to take advantage of a technical "expungent" $[$ sic $] \ldots . .38$

The Attorney General's decision, based on a strict congressional attitude toward narcotics offenders, was facilitated by the weakness of the Ringnalda doctrine. It is more persuasive, however, to realize at the outset that the reasoning of the Ringnalda court is now quite inappropriate because of changes in California law. By virtue of this, the pardon-expungement analogy is isolated, where it can be dealt with effectively in the light of the 1956 amendment. This latter approach, moreover, answers more clearly the dissent in Kelly $v$. Immigration \& Naturalization Serv. ${ }^{39}$ The dissent's first argument, based upon statements by a California jurist ${ }^{40}$ and California courts, ${ }^{41}$ is that deportation should not occur in the face of an

35 Immigration and Nationality Act $\$ 241$ (b), 66 Stat. 208 (1952), as amended, 8 U.S.C. § 1251(b) (1964).

${ }_{38}$ Garcia-Gonzales v. Immigration \& Naturalization Serv., 344 F.2d 804, 809 (9th Cir. 1965).

378 I. \& N. Dec. 429 (1959). This was the reconsideration of the order of deportation affirmed in Arrellano-Fiores v. Hoy, 262 F.2d 667 (9th Cir. 1958), cert. denied, 362 U.S. 921 (1960). Following the circuit court decision, the alien had obtained an expungement of his conviction and thus argued that his standing before the court, at which time he had not received an expungement, was sufficiently different that his deportation order should be reconsidered. This position was basically sound, since Arrellano-Flores had actually held only that the prospect of an expungement was ineffective against a deportation order.

388 I. \& N. Dec. at $445-46$.

39349 F.2d at 474.

40 Holland, supra note 11 , at 47 , quoted in $349 \mathrm{~F} .2 \mathrm{~d}$ at 477.

41 In re Trummer, 60 Cal. 2d 658, 660, 388 P.2d 177, 179, 36 Cal. Rptr. 281, 284 (1964) ; People v. Banks, 53 Cal. 2d 370, 386, 348 P.2d 102, 113 (1959), quoted in Kelly v. Immigration \& Naturalization Serv., 349 F.2d 473, 476-77 (9th Cir. 1965) (dissenting opinion). 
expungement because an expungement restores a defendant to his civil rights. ${ }^{42}$ But assuming freedom from deportation to be a civil right, the expungement does no more for the alien than does a pardon, which "shall entitle the person to exercise thereafter all civil and political rights of citizenship . . . 43 It also answers the dissent's charge that the Kelly v. Immigration \& Naturalization Serv. and Garcia-Gonzales decisions result in an inconsistent application of the deportation statute to narcotics cases, on the one hand, and nonnarcotics cases on the other. ${ }^{44}$ The inconsistency is shown to be a result of the statute itself and not its application.

The Garcia-Gonzales and Kelly v. Immigration \& Naturalization Serv. decisions are harsh. However, employment of the judicial leniency doctrine to reverse the deportation orders would clearly have contravened the intended application of present deportation law. The remedy thus lies with Congress.

It would appear preferable to return to the situation where a pardon or expungement could prevent deportation in narcotics cases. While narcotics control has become a serious federal problem, and there may be reason to believe that aliens are responsible for part of the drug traffic, ${ }^{45}$ it is hard to view the deportation of aliens such as those involved in these cases as an appropriate remedy. There seems to be no reason, moreover, for specifically excluding such narcotics offenders from that group of aliens as to whom a pardon or expungement may operate to prevent deportation. The exercise by state officials of discretion to grant a pardon or expungement is equally strong evidence of rehabilitation in a narcotics case as in other cases. Reasoning that narcotics use is a genre of criminality from which convicts are rarely rehabilitated seems inconsistent with the retention of the pardon clause in the case of the sex offender who, it is arguable, is equally resistant to rehabilitative measures. ${ }^{46}$ If the fear is that narcotics violations are so likely to recur that an expungement or pardon in such cases would mean little, or that state officials will be overly liberal in granting such relief, provision can be made to limit the effect of expungements or pardons to first offenses. This solution accepts a state determination that an alien is no longer to be regarded as a criminal and dangerous to society. If there is any basis to this state determination, the real reason for the alien's being deemed deportable in the first place no longer exists.

42 Id. at 477.

43 See text at note 31 supra.

44 See 349 F.2d at 479-80 (dissenting opinion).

45 See S. Rep. No. 725, 82d Cong., 1st Sess. 32 (1951); Hearings Before Special Senate Committee To Investigate Organized Crime in Interstate Commerce, 82d Cong., 1st Sess., pt. 14, at 344-48 (1951).

4666 Stat. 208 (1952), as amended, 8 U.S.C. $\$ 1251$ (b) (1964). The Board and the Attorney General have indicated that the rule of the narcotics provision will not be extended to the cases involving other convictions as ground for deportation. Matter of G-, 9 I. \& N. Dec. 159 (1960). 